\title{
Article
}

\section{Islanding Detection Strategy for Wind Farm Based on Performance Analysis of Passive Indices Having Negligible NDZ}

\author{
Nouman Shafique ${ }^{1}$, Safdar Raza ${ }^{1}\left(\mathbb{D}\right.$, Hafiz Mudassir Munir ${ }^{2}$, Syed Sabir Hussain Bukhari ${ }^{2,3}{ }^{(1)}$ \\ and Jong-Suk Ro ${ }^{3,4, *(D)}$ \\ 1 Department of Electrical Engineering, NFC Institute of Engineering \& Technology, Multan 60000, Pakistan; \\ noumans099@gmail.com (N.S.); safdar.raza@nfciet.edu.pk (S.R.) \\ 2 Department of Electrical Engineering, Sukkur IBA University, Sukkur 65200, Pakistan; \\ mudassir.munir@iba-suk.edu.pk (H.M.M.); sabir@iba-suk.edu.pk (S.S.H.B.) \\ 3 School of Electrical and Electronics Engineering, Chung-Ang University, Seoul 06974, Korea \\ 4 Department of Intelligent Energy and Industry, Chung-Ang University, Seoul 06974, Korea \\ * Correspondence: jongsukro@gmail.com
}

Citation: Shafique, N.; Raza, S.;

Munir, H.M.; Bukhari, S.S.H.; Ro, J.-S.

Islanding Detection Strategy for Wind

Farm Based on Performance Analysis of Passive Indices Having Negligible NDZ. Appl. Sci. 2021, 11, 9989.

https://doi.org/10.3390/app11219989

Academic Editors: Alfio Dario Grasso and Andreas Sumper

Received: 18 August 2021

Accepted: 22 October 2021

Published: 26 October 202

Publisher's Note: MDPI stays neutral with regard to jurisdictional claims in published maps and institutional affiliations.

Copyright: (c) 2021 by the authors. Licensee MDPI, Basel, Switzerland. This article is an open access article distributed under the terms and conditions of the Creative Commons Attribution (CC BY) license (https:// creativecommons.org/licenses/by/ $4.0 /)$.

\begin{abstract}
Distributed generation (DG) resources integration into power system results in environmental and economic benefits. However, technical challenges may create many problems for the distribution system. Islanding detection is the topmost technical perspective regarding distribution system protection. This paper devised a passive islanding detection strategy that employed voltage phase angle (VPA). The VPA is selected after the performance assessment of 6 passive indices. Comparative study proves that VPA has the best accuracy and sensitivity compared to other indices parameters. The proposed technique is employed on a generic system that easily distinguished islanding situations from non-islanding cases such as load increment, load decrement, capacitor energization, capacitor de-energization, motor starting, motor unloading and various types of faults switching scenarios. The protective method is simple and has a quick interpretation algorithm as compared to other existing methods. The study is carried out on IEEE 1547 general test system in MATLAB/SIMULINK environment. The proposed strategy has nearly zero non-detection zone.
\end{abstract}

Keywords: islanding; distributed energy resources (DER's); voltage phase angle (VPA); non-detection zone (NDZ); passive indices

\section{Introduction}

Distributed energy resources (DER's) are an integral part of power systems as their inclusion is to reduce environmental pollution, improve system flexibility, reduce power losses, meet the load demands and increase system efficiency from economic and technical perspectives [1]. DER's (generally consist of solar plants, wind farms, mini hydro's turbines, biomass, fuel cell and geothermal energies) generate power at a smaller scale compared to conventional power resources, also refer as distributed generation (DG) [2]. However, excess DG inclusion in the power system and their unpredictable nature may lead to technical problems for the loads as well as DG itself. Some of the technical problems are unsynchronized reclosing, power quality issues, system security, maloperation of protection schemes, system stability and reliability, islanding and voltage regulation [2-4].

Unintended islanding condition is the one of chief alarming state from a technical viewpoint for power system operation. A fault is identified by the security scheme of the grid but not by DG protection scheme, failure operation of equipment, malpractices, an act via nature and human mistake are the main reason behind unintended islanding condition [5]. In the islanding situation, DG is still energizing the local load in response to grid supply disruption. Islanding is an unsolicited condition in a power system that originates safety concerns for workers, power quality issues for load and unsynchronized closure that harms generation and supply services [6]. A standard for islanding detection 
"IEEE-STD 1547-2018" acclaims that after the islanding situation, it must be identified within $2 \mathrm{~s}$ [7].

Islanding recognition strategies are generally divided into two types such as remote methods and local methods. Each islanding detection method is assessed via non-detection zone (NDZ). NDZ is a region or area where the protection schemes are unable to recognize islanding conditions $[1,2,4]$. Remote strategies are based on communication links or channels between DG and utility. This method has zero NDZ, no impact on power quality, fast response and reliability. However, this method is non-economical due to the extra transmitter and receiver employed in the distribution system and without employing backup protection $[8,9]$. Common techniques of this method are supervisory control data acquisition (SCADA), power line carrier communication (PLCC) and transfer trip [9].

Local methods are further split into three categories: active, passive and hybrid methods. Active methods are based on the distortion signal injection in the power system to measure the output parameter variation. In grid-connected mode, there is no significant variation in the parameter as the grid side absorbs these signals. However, during islanding mode, there is an extreme alteration in the output parameter and this alteration leads to the initiation of the protection scheme. Active methods have insignificant NDZ compare to passive techniques $[2,8,10]$. However, this method creates power quality issues for load $[2,8]$. Generally used active islanding detection techniques are Sandia frequency/voltage shift (SFS/SVS) [11], virtual capacitor/inductor [12,13], current injection [14], active frequency drift (AFD) [15], phase-locked loop (PLL) signal injection [16] and high frequency signal injection-based schemes [17].

Passive methods are based on the measurement of a local parameter such as frequency, voltage, THD, etc. at the point of interconnection (POI) [1]. Islanding situation only identified when measured parameter value exceeds the predefined threshold value, then the relay sends a trip signal to the breaker of the DG unit [1,4]. Passive methods are easy to implement, simple, economical and regardless of power quality issues $[10,18]$. However, large NDZ and difficulty in threshold selection are the main drawbacks of passive methods $[10,19]$. Typically used passive methods are under/over voltage and frequency, phase jump in voltage, rate of change of frequency, rate of change of power and total harmonic distortion methods [1].

Some signal processing techniques combine with passive strategies to overcome drawbacks of passive methods just like wavelet transform (WT), wavelet packet transform (WPT) and S-transform (ST) [20-25]. Some recent contributions are fuzzy logic, artificial neural network, decision tree, Naive Bayesian classifier, Random Forest classifier are established in $[2,20,21,26-28]$. Active and passive islanding detection schemes are combined to form hybrid methods. These methods are developed to obtain the advantages of both types. A brief overview of hybrid methods is discussed in [2].

After observing the literature review, it has been realized that both the indices and rate of changes have been used for islanding detection in some contributions. 16 different rates of changes are considered and a new passive parameter based on the rate of change of frequency over reactive power $(\mathrm{df} / \mathrm{dq})$ is proposed in terms of sensitivity and performance. This technique is fast and simple. However, small NDZ is still a problem in this technique. Moreover, indices are not taken into account in this work [29]. A mathematical morphology-based method has used 6 passive indices for better effectiveness of protection scheme. Reactive power is the best in terms of simple methodology and quick implementation. However, NDZ still exists in this method [30]. A zero NDZ based and quick implementable passive islanding detection technique employed 2 passive indices viz. voltage and frequency variation. However, the use of 2 passive indices makes the algorithm complex and increases the computational burden [6]. Furthermore, few methods consider 2 passive indices for islanding detection such as negative sequence volt-age/current utilized phaslet algorithm [31], voltage/positive sequence voltage phase angle [32] and transient index voltage/positive sequence angle superimposed current [33]. The precision 
of these methods was high and have almost zero NDZ. Though, the usage of more indices makes the algorithm slightly complex.

Some recent contributions have been considered in the literature including VPA techniques. Passive methods have been developed in [31-39] to minimize the NDZ and tripping time. In [40], the active islanding detection method for inverter type DG is employed based on voltage phase angle. A difference between the instantaneous and nominal voltage phase angle (VPA) of a distributed generation (DG) is applied to inverter-based interface control. However, inconsequential power quality issue is still present in this method. The active method for inverter base DG has been presented in [41] uses voltage phase angle of inverter-based DG as a feedback signal to change powers references. However, insignificant power quality issues still exist. In [42], the passive islanding detection method has been developed by combining under frequency (UF), over frequency (OF), rate of change of frequency (ROCOF), phase angle difference, rate of change of voltage (ROCOV) and rate of change of phase angle difference (ROCOPAD). This method has the advantages of zero NDZ and fast tripping time. However, the algorithm becomes complex due to using multiple passive parameters. The communication-based method has been used in [43] by employing proposed parameters of voltage phase angle difference and rate of change of voltage phase angle difference (ROCOVPAD). Zero NDZ, fast detection time and no power quality impacts on the system are the advantages of this method. However, the use of GPS and wireless modems is economically not good from an economical perspective.

The abovementioned passive islanding detection methods are either suffer from one of the issues like NDZ, power quality issue, large tripping time or have complexity in the algorithm. Further, the comprehensive performance analysis of passive indices has not been considered for possible worst-case scenarios of islanding and non-islanding. Previously, the passive islanding detection methods show that a lot of in-depth analysis has been carried out on rates of changes. The few techniques are based on the analysis of indices but in-depth performance analysis of methods has not been anticipated regarding the selection of the most sensitive indice at nearly zero NDZ.

The paper is organized in the following way: Section 2 describes the power system description, analysis of passive indices, the proposed methodology and validation of selected parameters on a generic test system. Section 3 represents the simulation results, comparison along with NDZ assessment. Lastly, the conclusion is provided in Section 4.

\section{Materials and Methods}

The power system in this study comprises of doubly-fed induction generator (DFIG) wind farm, utility grid, parallel RLC load, grid and wind farm transformers altogether connected to $11 \mathrm{kV}, 50 \mathrm{~Hz}$ distribution system. Two circuit breakers $\left(\mathrm{CB}_{\mathrm{Grid}}, \mathrm{CB}_{\mathrm{DG}}\right)$ are connected to DG and grid respectively. DFIG contains an induction generator heaving wound rotor and PWM AC/DC/AC converter based on IGBT. AC/DC/AC converter provides variable frequency to the rotor whereas stator windings are directly linked with the power grid. Simulation parameters of the system are given in Table 1. These parameters are adjusted and varied to set desired testing cases. IEEE 1547 generic test system [44] is employed for validation of islanding detection technique performance as shown in Figure 1.

The control scheme of the DFIG can impact the behavior of different parameters during islanding events and abnormal conditions. The behavior of parameters can become unpredictable if control parameters deviate from default settings. The impact of the control scheme of DFIG on parameters mainly depends on the type of control and islanding detection strategy used.

The basic configuration of the DFIG wind turbine scheme is shown in Figure 2a-d. The DFIG control systems have two portions: mechanical control for wind turbine blade pitch angle and electrical control for DFIG. The controlling of DFIG is achieved through the control of voltage frequency converter $(\mathrm{AC} / \mathrm{DC} / \mathrm{AC})$ that further consists of control of grid side coveter (GSC) \& control of rotor side coveter (RSC) [45,46]. 


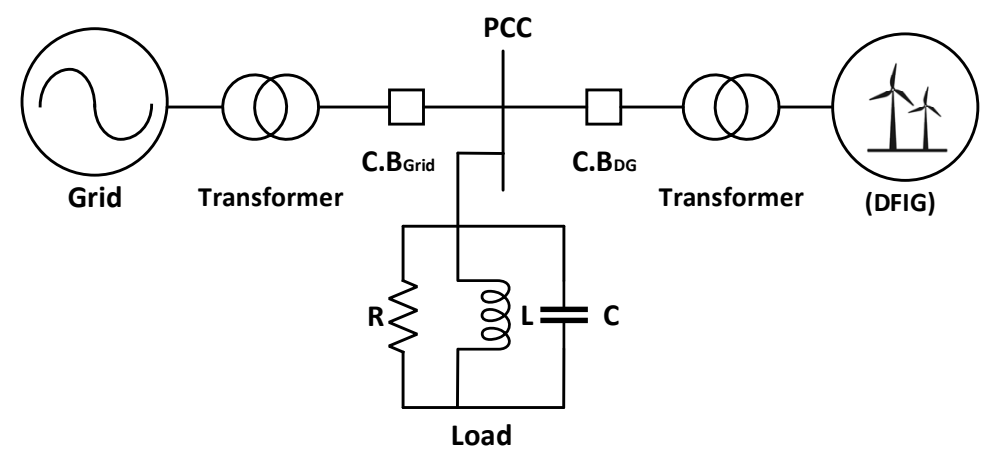

Figure 1. IEEE 1547 Generic test system.

Table 1. Parameters for Simulation.

\begin{tabular}{cl}
\hline Grid & $\mathrm{V}=230 \mathrm{kV} ; \mathrm{f}=50 \mathrm{~Hz}$ \\
\hline DFIG & $\mathrm{P}=2 \mathrm{MW}(1 \mathrm{MW} \times 2) ; \mathrm{V}=575 \mathrm{Volts} ; \mathrm{f}=50 \mathrm{~Hz} ; \mathrm{v}=15 \mathrm{~m} / \mathrm{s} ; \mathrm{Q}_{\text {ref }}=0.5 \mathrm{pu}$ \\
\hline \multirow{2}{*}{ Transformer Grid } & $\begin{array}{l}\mathrm{P}=5 \mathrm{MVA} ; \mathrm{f}=50 \mathrm{~Hz} ; \mathrm{R}_{1}=\mathrm{R}_{2}=0.0026 \mathrm{pu} ; \mathrm{L}_{1}=\mathrm{L}_{2}=0.08 \mathrm{pu} ; \\
\mathrm{L}_{\mathrm{M}}=\mathrm{R}_{\mathrm{M}}=500 \mathrm{pu}, 230 \mathrm{kV} / 11 \mathrm{kV}\end{array}$ \\
\hline \multirow{2}{*}{ Transformer DFIG } & $\mathrm{P}=1.25 \times 2 \mathrm{MVA} ; \mathrm{f}=50 \mathrm{~Hz} ; \mathrm{R}_{1}=\mathrm{R}_{2}=0.0008 \mathrm{pu} ; \mathrm{L}_{1}=\mathrm{L}_{2}=0.025 \mathrm{pu} ;$ \\
& $\mathrm{L}_{\mathrm{M}} / \mathrm{R}_{\mathrm{M}}=\mathrm{inf} / 500 \mathrm{pu}, 11 \mathrm{kV} / 575 \mathrm{~V}$ \\
\hline RLC Load Parallel & $1.7 \mathrm{MW} ; \mathrm{Q}_{\mathrm{L}}=1.5 \mathrm{MVar} ; \mathrm{Q}_{\mathrm{C}}=0.8 \mathrm{MVar} ; 11 \mathrm{kV} ; 50 \mathrm{~Hz}$ \\
\hline Induction motor & $400 \mathrm{hp} ; 11 \mathrm{KV} ; 50 \mathrm{~Hz} ;$ Inertia constant $=0.09526 \mathrm{~s}$ \\
\hline Capacitor bank & $\mathrm{Q}_{\mathrm{C}}=2 \mathrm{MVar} ; 11 \mathrm{kV} ; 50 \mathrm{~Hz}$ \\
\hline Short circuit Fault & $\mathrm{R}=50 \mathrm{ohm} ; \mathrm{R}_{\mathrm{g}}=0.01 \mathrm{ohm}$ \\
\hline
\end{tabular}

The main aims of control systems are [46]:

- $\quad$ RSC is responsible for the regulation of stator active and reactive independently.

- Irrespective of the direction and magnitude of rotor power, GSC maintains the DC link voltage.

- The wind turbine controller is responsible for controlling the blade pitch angle that measures the mechanical power extracted from a wind turbine.

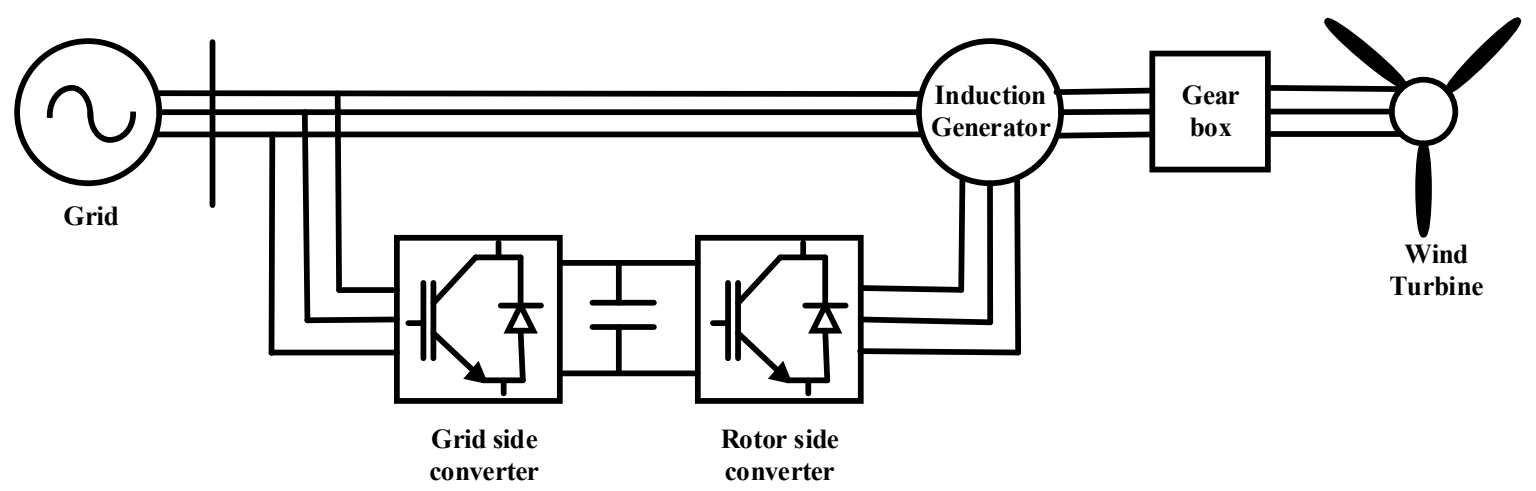

(a)

Figure 2. Cont. 


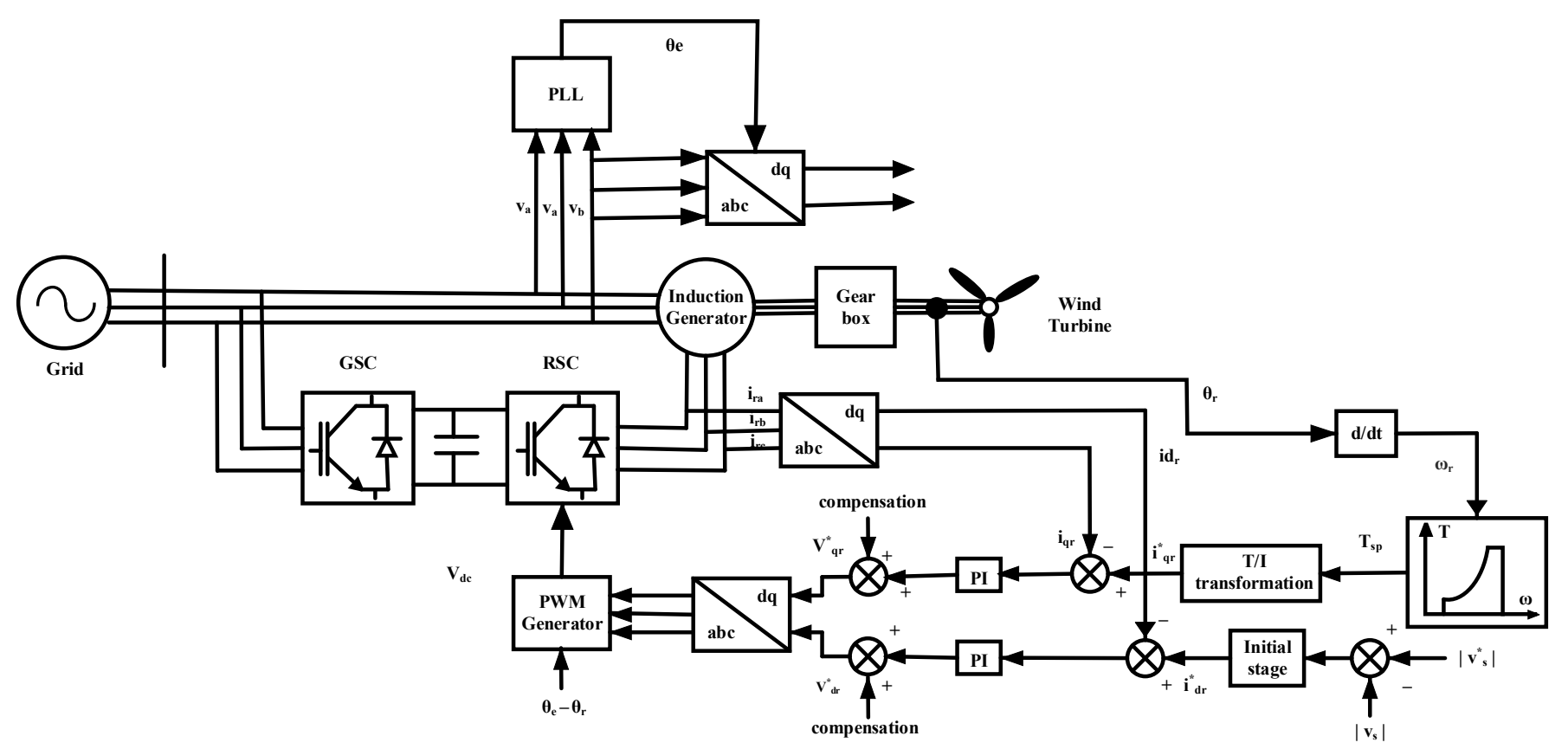

(b)

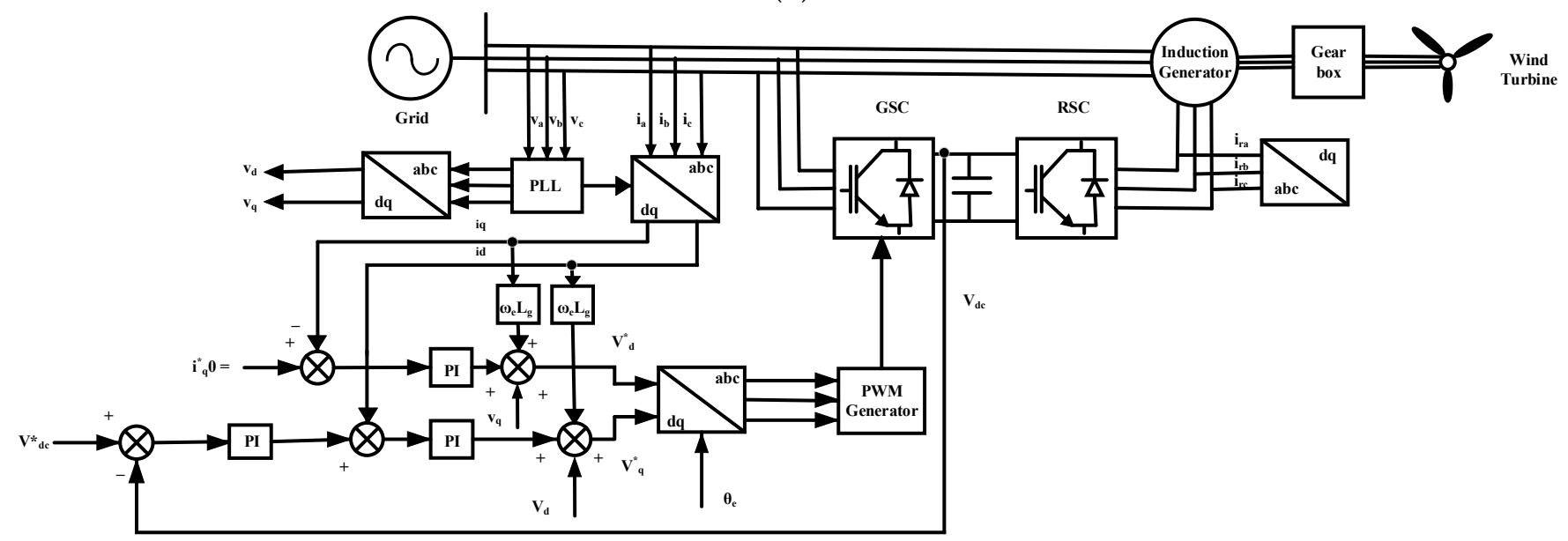

(c)

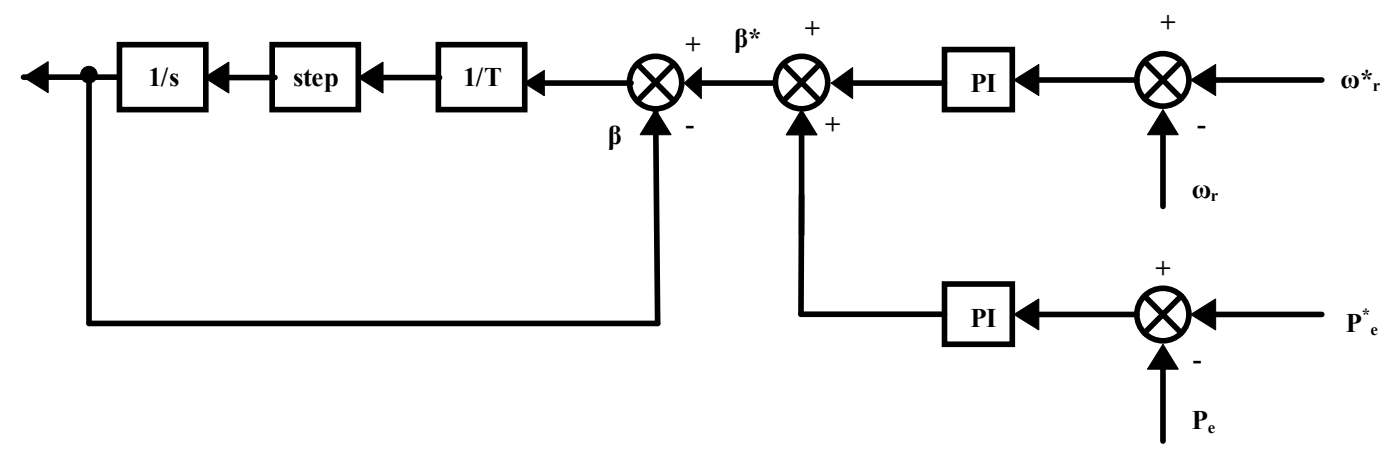

(d)

Figure 2. Control scheme of DFIG (a) A basic configuration of a DFIG wind turbine (b) Overall vector control scheme of the RSC (c) Overall vector control scheme of the GSC (d) Wind turbine pitch angle controller.

In our proposed method, a separate relay with synchro-phasor measurement functionality is used at a single DG connection point. However, when multiple DG's will be used then separate relays must be employed for every DG connection point. A multiple 
DFIG's network has employed in [6] used four separate relays for each DG connection point. Contrary to this, some inverter base DG has used the islanding detection control schemes added in the inverter control for gaining the cost-efficiency benefits. The inverterbased control schemes can be active or passive. However, the designing of inverter control schemes for islanding detection is complex as compared to passive methods. The proposed method in this study is independent of any type of inverter-based control.

In this work, 6 different passive indices are considered for analysis such as voltage, frequency, active power, reactive power, power factor and voltage phase angle. These 6 parameters are inspected on the power system under analysis as presented in Figure 1 via consideration of various islanding and non-islanding situations. Islanding situations include small mismatch (S.M) and large mismatch (L.M) condition whereas non-islanding or abnormal events comprises of load increment (L.I), load decrement (L.D), capacitor energization (C.E), capacitor de-energization (C.D), motor starting (M.S), motor unloading (M.U) and fault switching (F.S) scenarios. All considered situations are accomplished with power mismatch as tabulated in Table 2. The absolute values (magnitudes or phase) are noted for all considered indices after numerous islanding and non-islanding events are shown in Figure 3a-f.

After careful investigation of passive indices (voltage, frequency, active power, reactive power, power factor), it has been noted that the magnitude/phase of passive indices are intermixed for islanding vs. non-islanding scenarios as shown in Figure 3a-e. However, the voltage phase angle as shown in Figure $3 \mathrm{f}$ presents a considerable picture. Voltage phase angle differentiate islanding operations from non-islanding events.

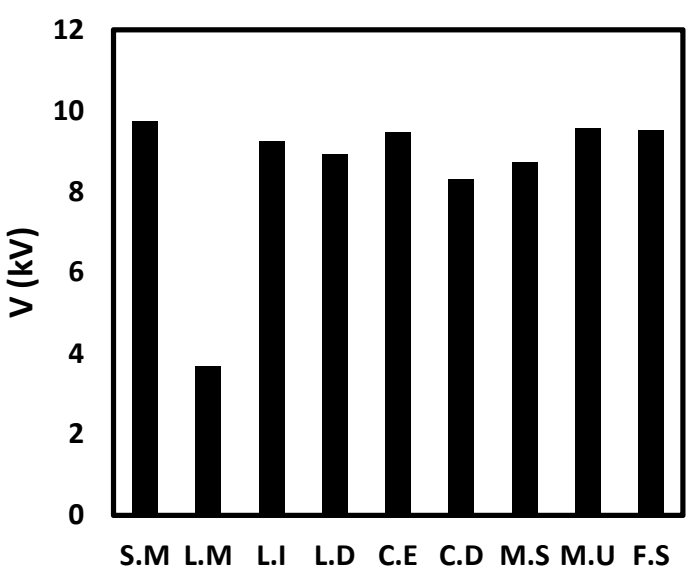

(a)

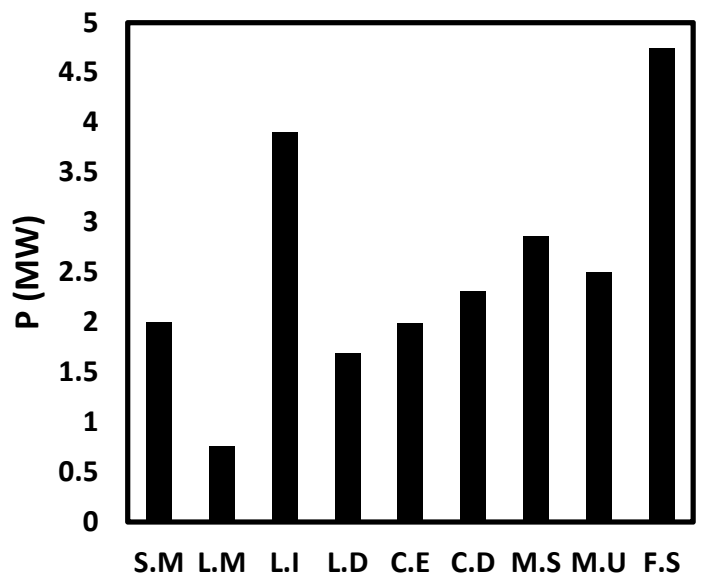

(c)

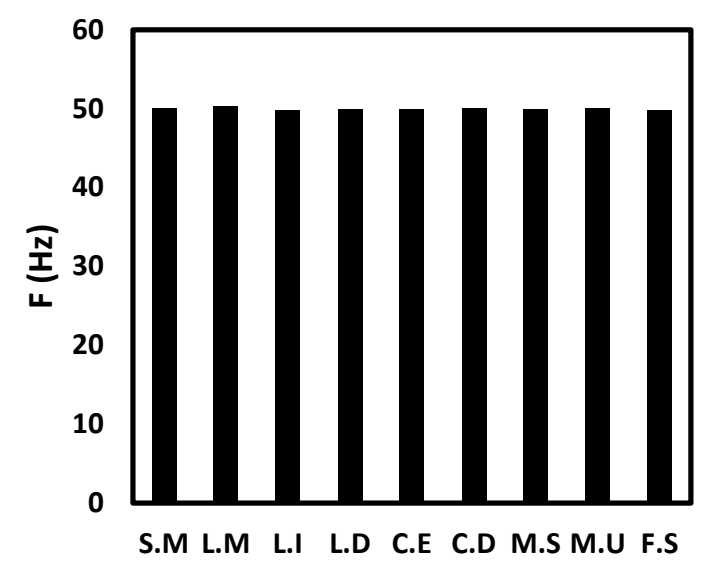

(b)

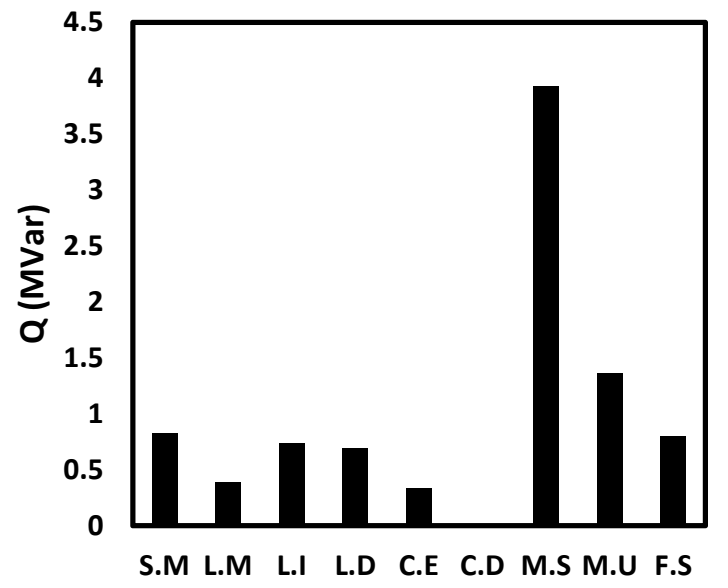

(d)

Figure 3. Cont. 


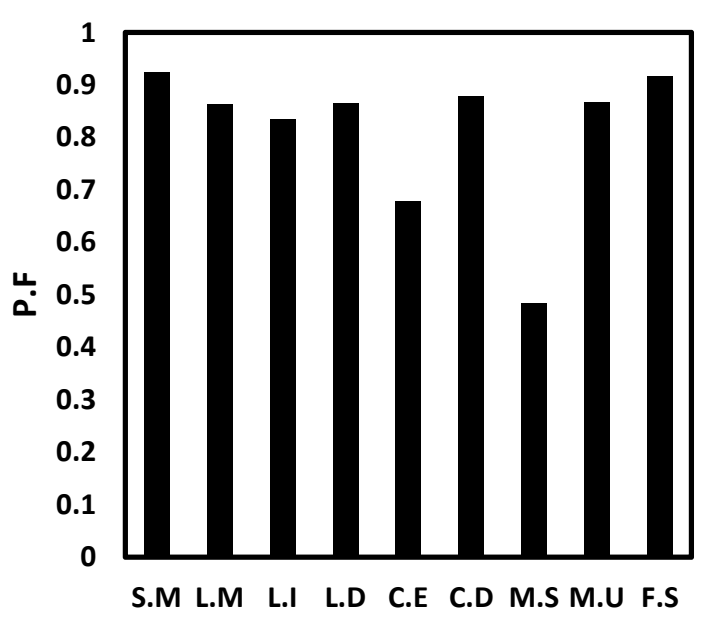

(e)

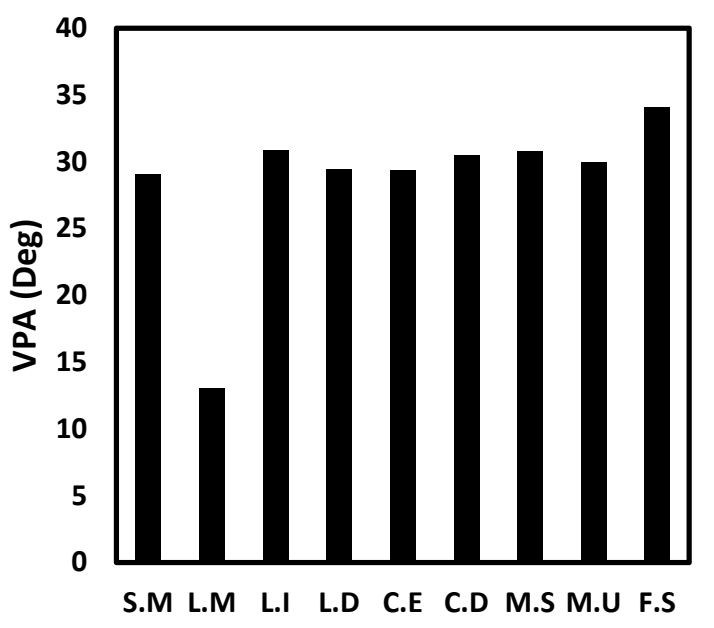

(f)

Figure 3. Comparison of parameters magnitudes/phase vs. considered islanding and non-islanding event (a) voltage (b) frequency $(\mathbf{c})$ active power $(\mathbf{d})$ reactive power $(\mathbf{e})$ power factor $(\mathbf{f})$ voltage phase angle.

Table 2. Testing scenarios.

\begin{tabular}{lcccccc}
\hline \multirow{2}{*}{ Testing Situations } & \multicolumn{2}{c}{ Grid Profiles } & \multicolumn{2}{c}{ Load Profiles } & \multicolumn{2}{c}{ DG Profiles } \\
\cline { 2 - 6 } & $\mathbf{P}$ (MW) & $\mathbf{Q}$ (MVar) & P (MW) & Q (MVar) & P (MW) & Q (MVar) \\
\hline Islanding (small mismatch) (P.M) & 0.001 & 0.001 & 2.001 & 0.821 & 2.000 & 0.820 \\
Islanding (large mismatch) (L.M) & 1.930 & 1.920 & 3.960 & 2.110 & 2.030 & 0.200 \\
Load increment (L.I) & 0.001 & 0.001 & 2.001 & 0.821 & 2.000 & 0.820 \\
Load decrement (L.D) & 1.340 & 1.320 & 3.350 & 1.740 & 2.020 & 0.420 \\
Capacitor energization (C.E) & 0.001 & 0.001 & 2.001 & 0.821 & 2.000 & 0.820 \\
Capacitor de-energization (C.D) & 0.670 & 0.680 & 2.670 & 0.970 & 2.030 & 0.670 \\
Motor starting (M.S) & 0.001 & 0.001 & 2.001 & 0.821 & 2.000 & 0.820 \\
Motor unloading (M.U) & 0.840 & 0.820 & 2.840 & 1.590 & 2.030 & 0.760 \\
Fault switching (F.S) & 0.001 & 0.001 & 2.001 & 0.821 & 2.000 & 0.820 \\
\hline
\end{tabular}

On the other hand, the main concern can be highlighted regarding rapid normal frequency fluctuations when the penetration level of DG's will increase. This can tend to the maloperation of passive methods. Maloperation of relay can be expected at severe sensitive settings and less setting that can result in large NDZ. The main aim of performance analysis is to determine the power indices that can observe the minor disturbances proficiently. The performance analysis of power system parameters has assured the capability of a selected parameter in terms of moderate threshold setting without causing maloperation of the scheme. Parameter used without performance analysis could be vulnerable to maloperation. The selected parameter gives a clear picture that it will give a maloperation-less strategy and differentiate islanding from a non-islanding operation. Our proposed method has nearly zero NDZ because we avoid a less sensitive threshold setting. Hence, without performance analysis of power system parameters selection of threshold is very difficult.

Assessment of passive indices presented above demonstrates that voltage phase angle (VPA) has the best capability in terms of performance and sensitivity among all other passive parameters. Therefore, VPA is employed in the islanding detection process. The flow chart of the proposed strategy is shown in Figure 4. The proposed method measures absolute VPA at every half cycle. The strategy is activated when Equation (1) is satisfied:

$$
(\mathrm{VPA})_{\text {measured }}<(\mathrm{VPA})_{\text {threshold }}
$$

where (VPA) measured is the measured absolute mean value and (VPA) threshold is the predefined threshold. For (VPA) threshold, phase magnitudes of VPA during islanding and 
non-islanding is measured at power mismatches. Then a comparison of phase magnitudes of islanding and non-islanding is made so that which event shows higher or lower magnitudes. For our study, islanding events magnitudes are lower than the non-islanding events. That's why Equation (1) has been developed. The threshold selection is based on the specifications of the power system and has been found using the hit and trial process.

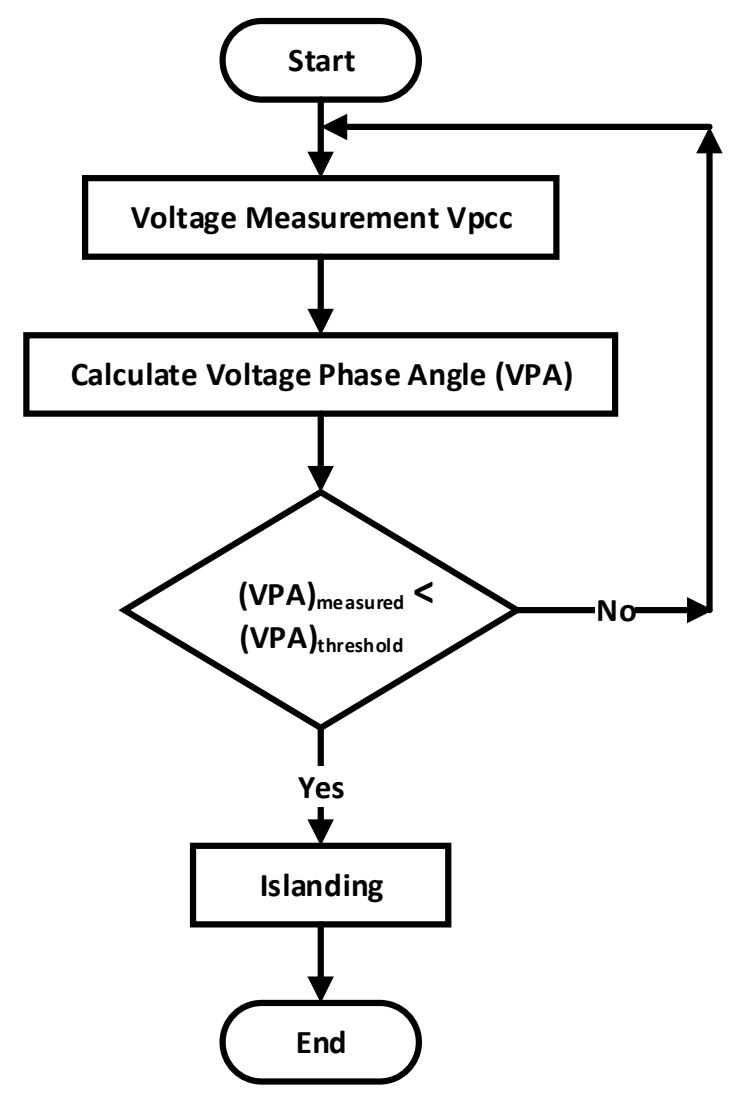

Figure 4. Flowchart of the proposed scheme.

Magnitudes/phase of the balanced or unbalanced three-phase signal is calculated with the help of sequence analyzer block in MATLAB/SIMULINK environment. The positive, negative and zero sequence components can be examined one by one or can be in combined formed at PCC (point of common coupling) and is expressed by Equation (2):

$$
\begin{gathered}
{\left[\begin{array}{l}
\mathrm{V}_{1} \\
\mathrm{~V}_{2} \\
\mathrm{~V}_{0}
\end{array}\right]=\frac{1}{3}\left[\begin{array}{ccc}
1 & 1 & 1 \\
1 & a & a^{2} \\
1 & a^{2} & a
\end{array}\right]\left[\begin{array}{l}
\mathrm{V}_{\mathrm{a}} \\
\mathrm{V}_{\mathrm{b}} \\
\mathrm{V}_{\mathrm{c}}
\end{array}\right]} \\
a=1 \angle 120^{\circ}
\end{gathered}
$$

where index $V_{1}, V_{2}, V_{3}$ are the positive, negative and zero sequence components and $\mathrm{V}_{\mathrm{a}}, \mathrm{V}_{\mathrm{b}}, \mathrm{V}_{\mathrm{c}}$ are phase voltage signals. " $a$ " denotes complex operator as in Equation (3). Analysis of harmonics is optional and can also be formed by providing "Harmonic n". A Fourier analysis is employed on a three-phase input signal for one cycle of the specific frequency that is based on a sliding window concept. At the specific fundamental or harmonic frequency, phase values $\mathrm{V}_{\mathrm{a}}, \mathrm{V}_{\mathrm{b}}, \mathrm{V}_{\mathrm{c}}$ are estimated. Then positive, negative and zero sequence components are obtained with help of transformation. The default parameter setting for the sequence analyzer block is tabulated in Table 3. 
Table 3. Parameters setting for sequence analyzer block.

\begin{tabular}{ll}
\hline Parameters & Values \\
\hline Frequency Hz & 50 \\
Harmonic $\mathrm{n}$ & 1 (fundamental) \\
Sequence & Positive sequence \\
Initial Input [Magnitude,Phase (degree)] & {$[1,0]$} \\
Sample time & $0 \mathrm{~s}$ \\
\hline
\end{tabular}

The parameters measured values in Figure 3 are representing the absolute mean values of selected indices for post islanding and non-islanding events. In our proposed scheme, 3-phase rms voltage is computed initially and then its mean and absolute measured values are determined respectively after that.

Assume a basic two-network three-phase system as shown in Figure 5. The phase to neutral voltages for a balanced three-phase system with phase sequence abc is given by Equations (4)-(6) respectively.

$$
\begin{gathered}
\mathrm{V}_{\mathrm{an}}=\mathrm{V}_{\mathrm{a}}=\mathrm{V} \angle 0^{\circ} \\
\mathrm{V}_{\mathrm{bn}}=\mathrm{V}_{\mathrm{b}}=\mathrm{V} \angle-120^{\circ} \\
\mathrm{V}_{\mathrm{cn}}=\mathrm{V}_{\mathrm{c}}=\mathrm{V} \angle+120^{\circ}=\mathrm{V} \angle-240^{\circ}
\end{gathered}
$$

where $V_{a n}, V_{b n}, V_{c n}$ represents the line to neutral voltages of three-phase voltage signal phases $a, b$ and $c$. The Equations (4)-(6) represent just a basic phase angle relationship between phases. In a normal mode of operation, the voltage of each phase at PCC is balanced and $120^{\circ}$ apart from each other. However, the islanding mode of operation will cause the deviation from nominal value depending upon islanding and abnormal events. The phase magnitude of any phase is almost $0^{\circ}$ in normal conditions. The second and third will be at $120^{\circ}$ and $240^{\circ}$ phase apart. In our proposed method, whatever the value of the 3-phase signal during balanced, islanding or abnormal conditions, we have used the absolute mean value measured value for better analysis.

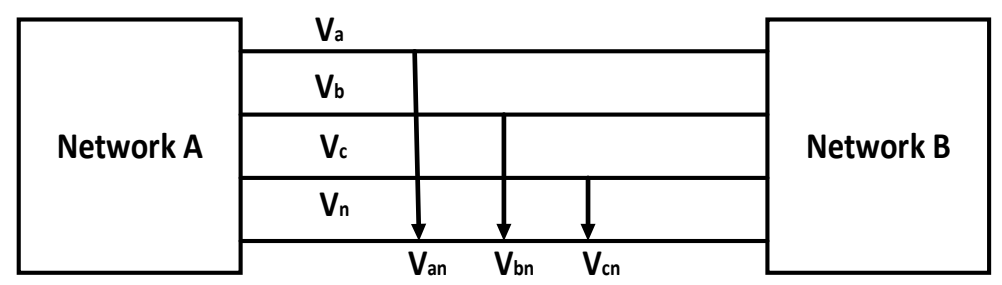

Figure 5. Two network system.

\section{Results}

The proposed strategy is evaluated by considering the IEEE 1547 system as shown in Figure 1. Islanding and abnormal cases are initiated at $5 \mathrm{~s}$ once the power system is stabilized. The threshold value for this study is set as $29.20^{\circ}$ (degree). The threshold is adjusted in such a way that magnitudes of non-islanding events become greater whereas magnitudes of islanding events become less than the threshold.

\subsection{Islanding Detection at Small Power Mismatch}

In a small power mismatch situation, a power mismatch of $0.001 \mathrm{MW}$ and $0.001 \mathrm{MVar}$ is considered between the load and DFIG. The response of this situation along with a trip signal is shown in Figure 6a,b. The (VPA) measured in this case is $29.16^{\circ}$ which is less than the threshold. Detection time in this process is $0.0928 \mathrm{~s}$ Hence, the protection strategy easily illustrates this case as an islanding operation. 


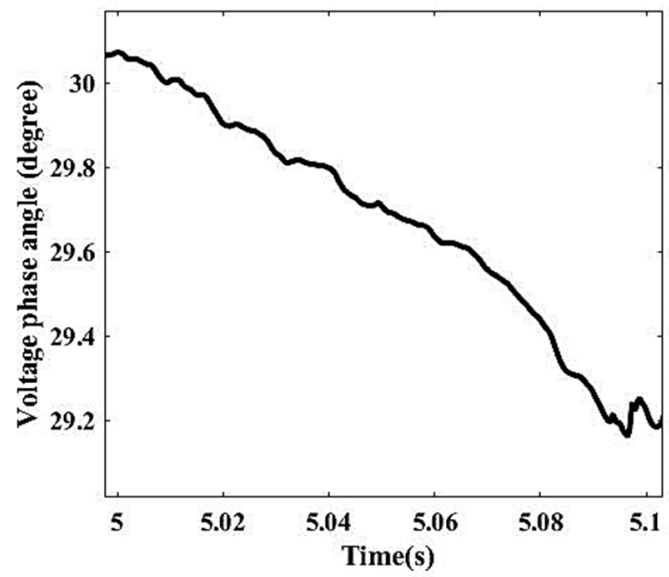

(a)

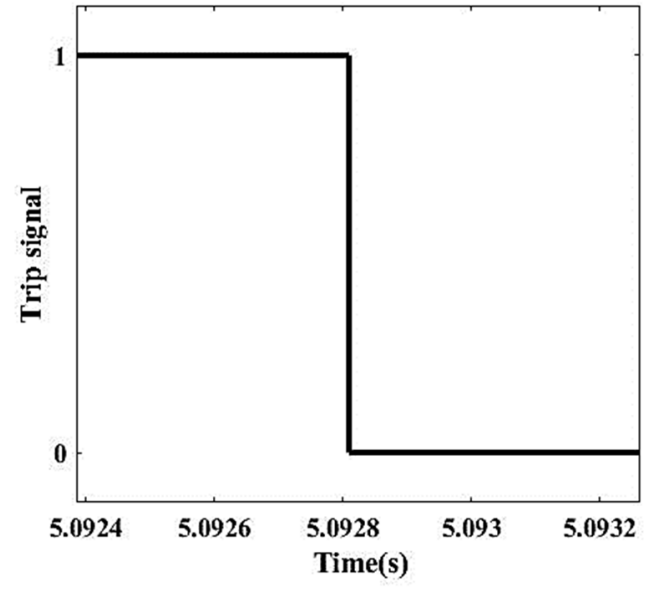

(b)

Figure 6. Islanding at small power mismatch situation (a) magnitude of voltage phase angle magnitude vs. time (b) detection time.

\subsection{Islanding Operation at Large Power Mismatch}

In this scenario, the grid delivers active and reactive power of about $1.93 \mathrm{MW}$ and 1.92 MVar respectively. (VPA) measured recorded for this situation is $13.17^{\circ}$, still less than the threshold. Islanding is detected in $0.0276 \mathrm{~s}$ for this event. The response of this case is shown in Figure 7a,b. Consequently, the protection strategy identifies this condition as islanding and sends a trip signal to the DFIG breaker.

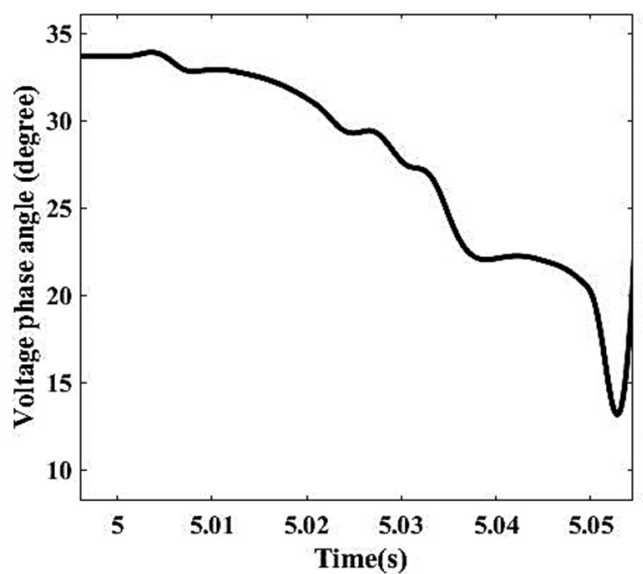

(a)

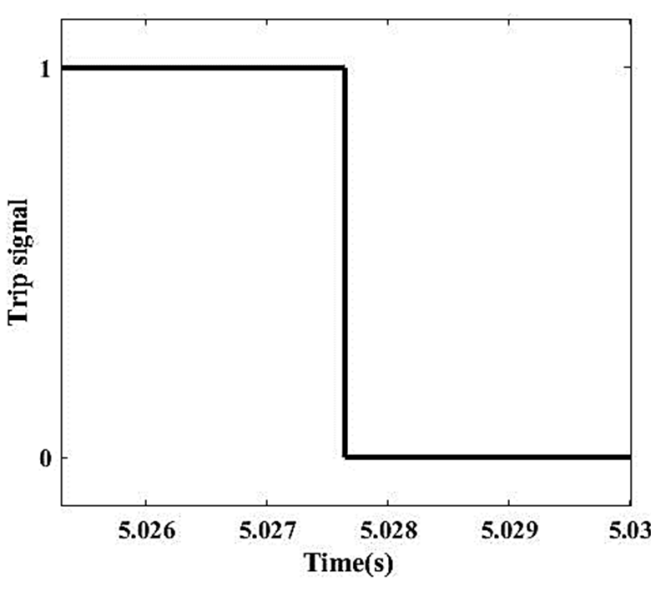

(b)

Figure 7. Islanding operation at large power mismatch situation (a) magnitude of voltage phase angle magnitude vs. time (b) detection time.

\subsection{Load Increment and Decrement}

A parallel RLC load of 1.95 MW and 1.2 MVar is incremented and decremented to check the working of the proposed technique. (VPA) measured for increasing and decreasing load are $30.90^{\circ}$ and $29.47^{\circ}$ which becomes greater than the threshold. Thus, the detection technique easily discriminates this event as non-islanding. The behavior of this scenario is presented in Figure 8a,b. 


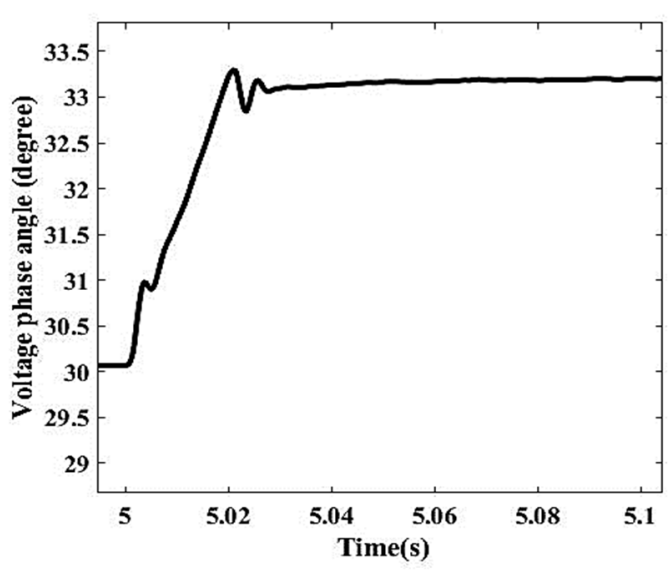

(a)

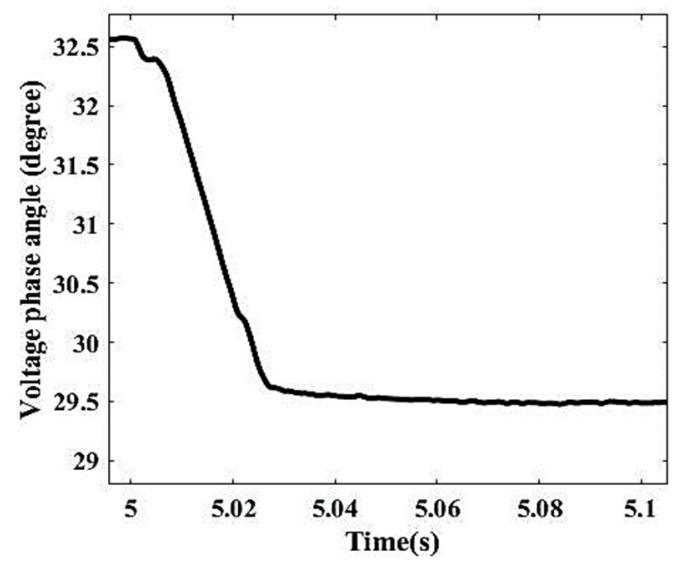

(b)

Figure 8. Magnitude of voltage phase angle during load switching scenarios (a) load increment (b) load decrement.

\subsection{Capacitor Energization and De-Energization}

A capacitor bank of 2 MVar is connected and disconnected from the power system under study. The switching of this event is shown in Figure $9 a, b$. The (VPA) measured for connection and disconnection of the capacitor bank is $29.35^{\circ}$ and $30.51^{\circ}$ which are greater than the threshold. The proposed technique, therefore, defines these switching cases as non-islanding cases.

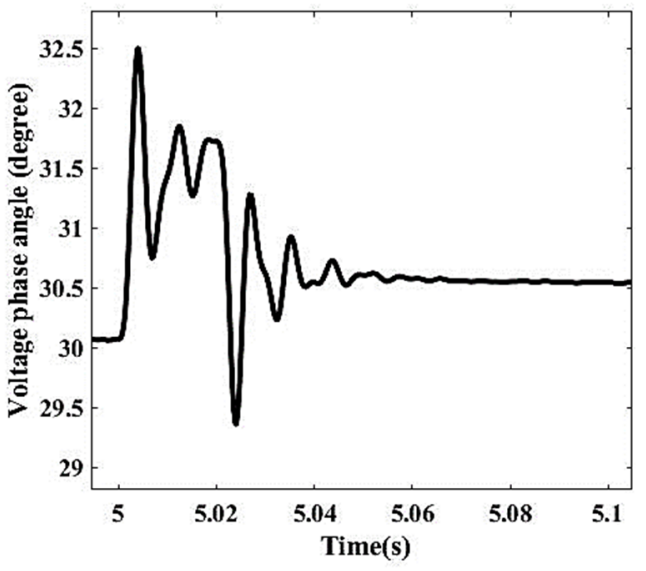

(a)

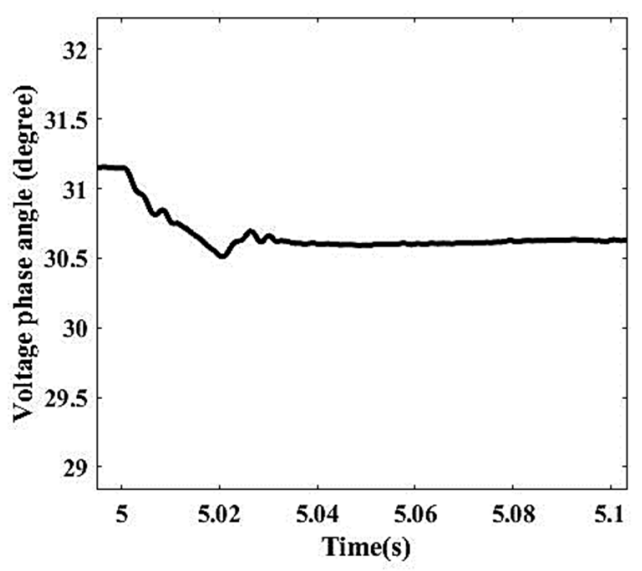

(b)

Figure 9. Magnitude of voltage phase angle during capacitor switching operations (a) Energization of a capacitor (b) De-energization of capacitor.

\subsection{Motor Starting and Unloading}

An induction motor with a bearing capacity of $400 \mathrm{hp}$ is started and unloaded to check its impact on the protection method. The recorded value of (VPA) measured for starting and unloading are $29.97^{\circ}$ and $30.83^{\circ}$ which are greater than the threshold. Thus, the scheme precisely recognizes this event as an islanding condition. The scenario is shown in Figure 10a,b. 


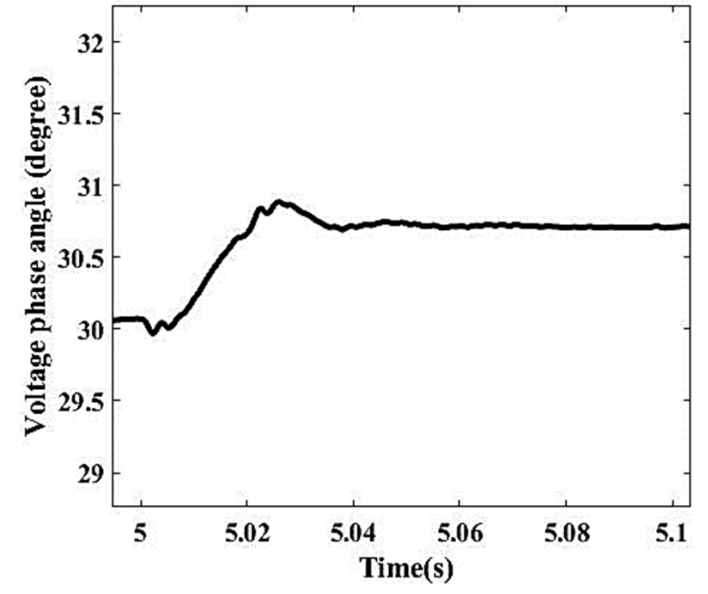

(a)

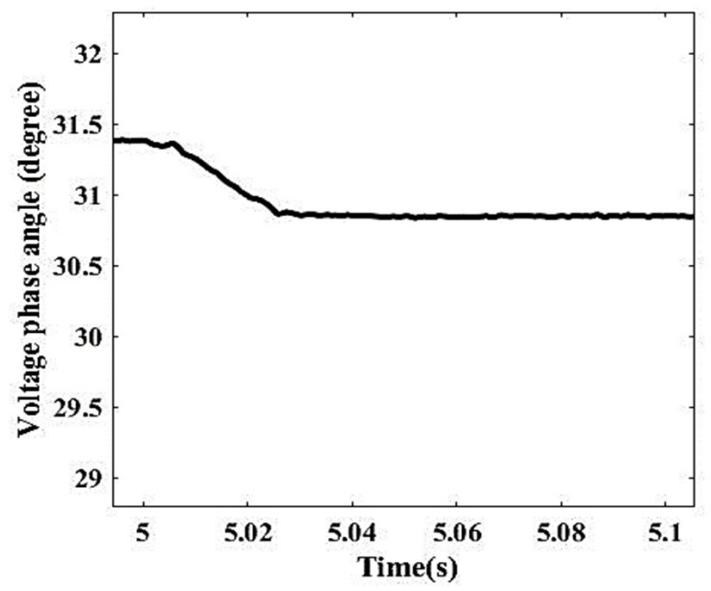

(b)

Figure 10. Magnitude of voltage phase angle during motor operation (a) Starting of induction motor (b) Unloading of induction motor.

\subsection{Fault Switching}

Fault types such as three-phase to ground (ABCG), three phases $(A B C)$, two phases to ground (ABG), single line to ground (AG) and double line $(A B)$ are imposed on the power system to check the effectiveness of the method. A fault is initiated for a short duration of $0.04 \mathrm{~s}$ with a resistance of $50 \Omega$. (VPA) measured for ABCG, ABC, ABG, AG and AB are $34.11^{\circ}$, $34.11^{\circ}, 30.57^{\circ}, 29.94^{\circ}$ and $30.53^{\circ}$. which are greater than the threshold. The magnitudes of voltage phase angle during these fault types are illustrated in Figure 11a-e. Thus, strategy classifies this scenario as a non-islanding event.

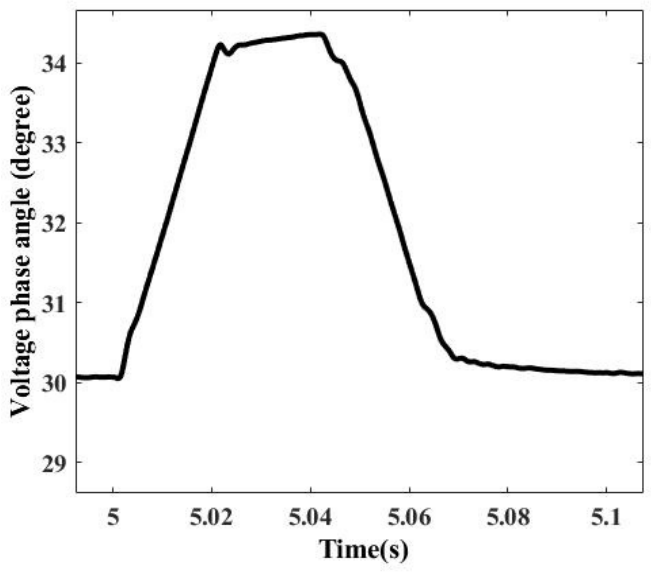

(a)

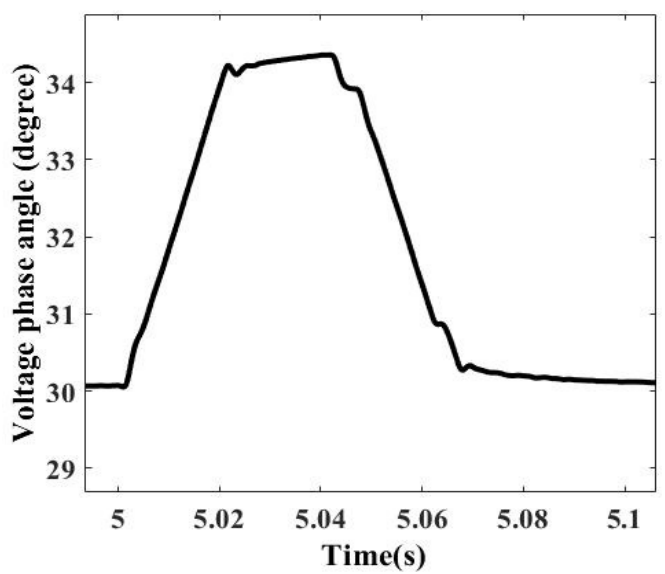

(b)

Figure 11. Cont. 


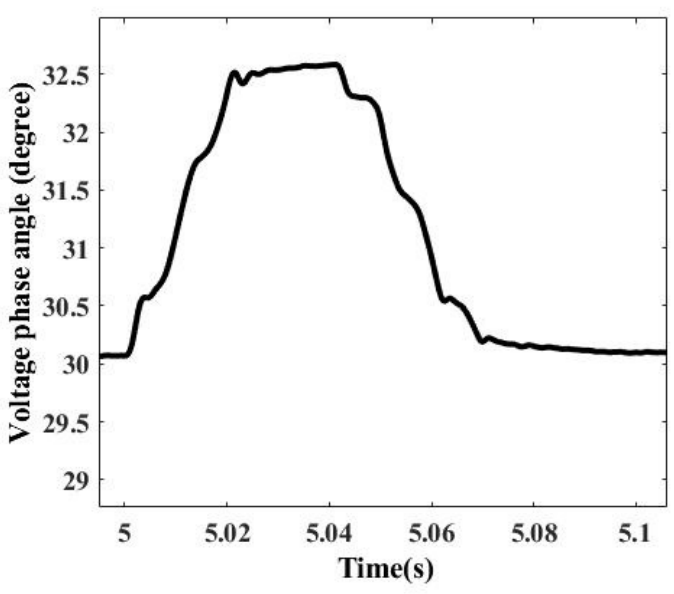

(c)

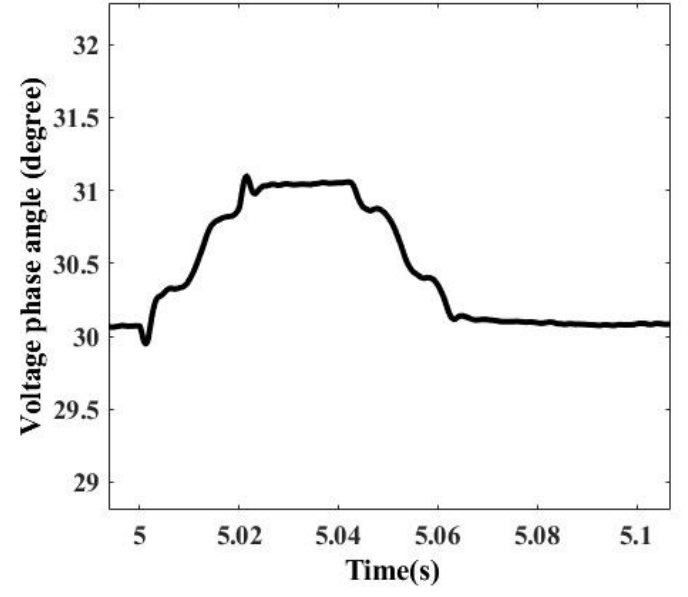

(d)

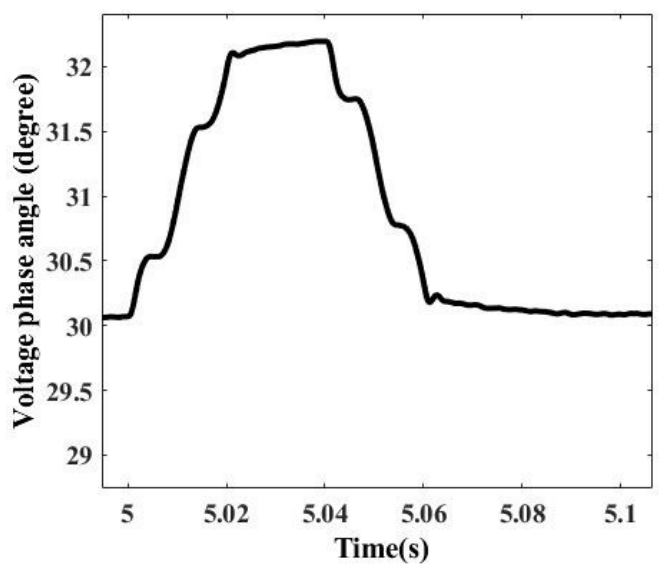

(e)

Figure 11. Magnitude of voltage phase angle during fault switching conditions (a) three-phase to ground (ABCG) fault (b) three-phase (ABC) fault (c) two-phase to ground (ABG) fault (d) AG one phase to ground (AG) fault (e) two-phase (AB) fault.

\subsection{Assessment of NDZ and Comparison of Existing Islanding Detection Strategies}

NDZ is the main criterion that reflects the effectiveness of the islanding recognizing method. It is an area where protection techniques are unable to recognize islanding conditions. For active power NDZ, is determined by [47]:

$$
\Delta \mathrm{P}=-3 \mathrm{~V} \times \Delta \mathrm{V} \times \mathrm{I} \times \cos \varphi
$$

where $\Delta \mathrm{P}$ is the active power mismatch, $\mathrm{V}$ and I are the rated voltage and current respectively, $\Delta \mathrm{V}$ is the voltage deviation and $\cos \varphi$ is the power factor.

The allowable voltage variations in the distribution network under study are $0.9 \mathrm{pu}$ and $1.1 \mathrm{pu}$. Considering these voltage levels, deviation $\Delta \mathrm{V}$ is -0.1 and 1.1 , respectively. The NDZ region of active power mismatch $\Delta \mathrm{P}$ studied for this system is $+0.20 \mathrm{MW}$ and $-0.20 \mathrm{MW}$.

For reactive power NDZ, is determined by [47]:

$$
\Delta Q=\frac{3 V^{2}}{\omega_{n} L}\left(1-\frac{f_{n}^{2}}{\left(f_{n} \pm \Delta f\right)^{2}}\right)
$$

where $\mathrm{V}$ is the rated voltage, $\mathrm{f}$ in the nominal frequency, $\Delta \mathrm{f}$ is the frequency deviation and $\omega_{\mathrm{n}}=2 \times \pi \times \mathrm{f}$. 
The allowable range for frequency variation $\Delta \mathrm{f}$ lies between $-0.5 \mathrm{~Hz}$ to $0.5 \mathrm{~Hz}$. Hence, $\mathrm{NDZ}$ of the study system with respect to reactive power mismatch is $0.2128 \mathrm{MW}$ and $-0.2192 \mathrm{MW}$. Simulation results also reveal that when power mismatch is $0.001 \mathrm{MW}$ and 0.001 MVar, the proposed scheme working efficiently. Compared to convention techniques of OF/UF (over frequency/under frequency) and OV/UV (over voltage/under voltage), the proposed technique enhances the accuracy and insignificant the NDZ as shown in Figure 12.

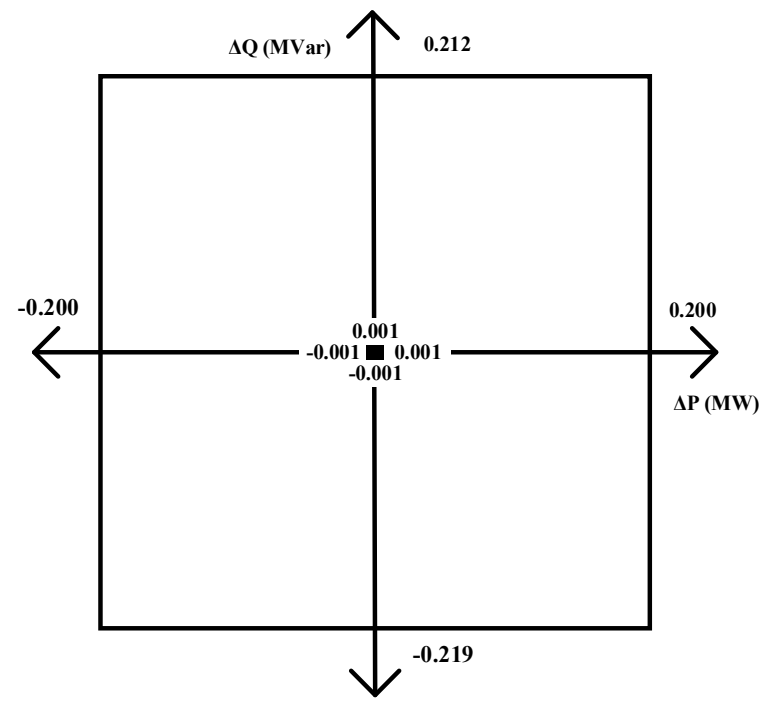

Figure 12. NDZ plot of the proposed strategy.

The analysis of passive indices presented in Section 2 reveals that voltage phase angle exhibits the best performance in terms of sensitivity and islanding detection time. Islanding operation only recognizes when the magnitude of voltage phase angle becomes less than the predefined threshold. Non-islanding events magnitudes remain greater than the threshold in comparison to islanding events. A brief overview of some existing islanding detection methods including the proposed strategies is compared based on detection time, non-detection zone, method type, power quality, algorithm complexity and concept used are presented in Table 4.

Table 4. Comparison of existing islanding detection strategies.

\begin{tabular}{|c|c|c|c|c|c|c|}
\hline Refs & Concept & Method & NDZ & $\begin{array}{l}\text { Detection } \\
\text { Time }\end{array}$ & $\begin{array}{c}\text { Algorithm } \\
\text { Complexity }(\mathrm{E} / \mathrm{M} / \mathrm{T})\end{array}$ & $\begin{array}{l}\text { Power Quality } \\
\text { Issues }\end{array}$ \\
\hline Proposed & Voltage phase angle variation & Passive & Near zero & $\leq 0.093 \mathrm{~s}$ & Easy & No \\
\hline & Voltage and frequency variation & Passive & zero & $<0.3 \mathrm{~s}$ & Medium & No \\
\hline$[36]$ & $\begin{array}{l}\text { Rate of change of exciter voltage } \\
\text { over reactive power }\end{array}$ & Passive & zero & $<2 \mathrm{~s}$ & Medium & No \\
\hline [37] & Rate of change of reactive power & Passive & very small & $0.10 \mathrm{~s}$ & Medium & No \\
\hline [38] & $\begin{array}{l}\text { ROCOF and Voltage-frequency } \\
\text { variations }\end{array}$ & Passive & very small & $\leq 0.17 \mathrm{~s}$ & Tough & No \\
\hline$[30]$ & $\begin{array}{l}\text { Rate of change of frequency over } \\
\text { reactive power }\end{array}$ & Passive & small & $0.2 \mathrm{~s}$ & Medium & No \\
\hline$[31]$ & $\begin{array}{l}\text { Reactive power variation } \\
\text { (Mathematical Morphology) }\end{array}$ & Passive & small & $\leq 0.8 \mathrm{~s}$ & Medium & No \\
\hline [32] & $\begin{array}{l}\text { Negative sequence voltage \& } \\
\text { current }\end{array}$ & Passive & zero & $0.02 \mathrm{~s}$ & Tough & No \\
\hline [33] & Transient index voltage & Passive & small & $0.02 \mathrm{~s}$ & Tough & No \\
\hline [34] & $\begin{array}{l}\text { Positive sequence voltage } \\
\text { (Entropy concept) }\end{array}$ & Passive & small & $0.06 \mathrm{~s}$ & Tough & No \\
\hline
\end{tabular}


Table 4. Cont.

\begin{tabular}{|c|c|c|c|c|c|c|}
\hline Refs & Concept & Method & NDZ & $\begin{array}{l}\text { Detection } \\
\text { Time }\end{array}$ & $\begin{array}{c}\text { Algorithm } \\
\text { Complexity }(\mathrm{E} / \mathrm{M} / \mathrm{T})\end{array}$ & $\begin{array}{l}\text { Power Quality } \\
\text { Issues }\end{array}$ \\
\hline [39] & EMD \& Entropy concept & Passive & very small & $<0.01 \mathrm{~s}$ & Tough & No \\
\hline [40] & Change in impedance & Passive & very small & $<0.02 \mathrm{~s}$ & Moderate & No \\
\hline [41] & Voltage phase angle difference & Active & small & $<0.5 \mathrm{~s}$ & Easy & Yes \\
\hline [42] & Voltage phase angle & Active & small & ${ }^{*} \mathrm{NA}$ & Easy & Yes \\
\hline [43] & VPA difference \& ROCOVPAD & Remote & zero & $<0.014 \mathrm{~s}$ & Tough & No \\
\hline [44] & $\begin{array}{l}\text { UF/OF, ROCOF, ROCO, } \\
\text { ROCOPAD, VPA }\end{array}$ & Passive & zero & $<0.06 \mathrm{~s}$ & Tough & No \\
\hline [45] & $\begin{array}{l}\text { State variables \& RC load } \\
\text { strategy }\end{array}$ & Hybrid & zero & $0.12 \mathrm{~s}$ & Moderate & No \\
\hline [46] & Voltage variation & Active & very small & $<0.3 \mathrm{~s}$ & Easy & No \\
\hline
\end{tabular}

\section{Conclusions}

The installation of distributed generation units in the power system creates an islanding situation that is damaging to equipment and grid personnel. This paper presents a passive islanding detection technique employing voltage phase angle. The voltage phase angle is selected after the comprehensive performance evaluation of six different passive power indices. The algorithm initially measures the voltage at the point of common coupling then it computes the measured value of voltage phase angle. Then the measured value is compared with the threshold for a decision regarding the islanding or non-islanding event. The proposed algorithm easily discriminates the islanding operations at small and large power mismatches from non-islanding operations just like load increment and decrement, capacitor energization and de-energization, motor starting and unloading and various kinds of faults switching. The performance of the anticipated strategy is being authenticated and modeled on the IEEE-1547 generic tests system. The suggested strategy is simple and straightforward, negligible non-detection zone (NDZ) and has no power quality impacts, thus making it a better choice for real-time implementation. The proposed method can be applied to any other IEEE benchmark system or custom-made network.

Author Contributions: Conceptualization, N.S. and S.R.; methodology, N.S.; software, N.S., H.M.M.; validation, N.S. and S.R.; formal analysis, N.S. and S.R.; investigation, N.S. and S.R.; resources, N.S., S.S.H.B. and J.-S.R.; data curation, S.R.; writing—original draft preparation, N.S.; writing—review and editing, S.R., J.-S.R.; visualization, N.S., S.R., S.S.H.B. and J.-S.R.; supervision, S.R. and J.-S.R. All authors have read and agreed to the published version of the manuscript.

Funding: This work was supported in part by the Brain Pool (BP) Program funded by the Ministry of Science and ICT through the National Research Foundation of Korea under Grant 2019H1D3A1A0110 2988, in part by the Basic Science Research Program through the National Research Foundation of Korea funded by the Ministry of Education under Grant 2016R1D1A1B01008058, and in part by the Competency Development Program for Industry Specialists of the Korean Ministry of Trade, Industry and Energy (MOTIE), operated by the Korea Institute for Advancement of Technology (KIAT) (No. P0002397, HRD program for Industrial Convergence of Wearable Smart Devices.

Conflicts of Interest: The authors declare no conflict of interest.

\section{References}

1. Manikonda, S.K.; Gaonkar, D.N. Comprehensive review of IDMs in DG systems. IET Smart Grid 2019, 2, 11-24. [CrossRef]

2. Abd-Elkader, A.G.; Allam, D.F.; Tageldin, E. Islanding detection method for DFIG wind turbines using artificial neural networks. Int. J. Electr. Power Energy Syst. 2014, 62, 335-343. [CrossRef]

3. Manditereza, P.T.; Bansal, R. Renewable distributed generation: The hidden challenges-A review from the protection perspective. Renew. Sustain. Energy Rev. 2016, 58, 1457-1465. [CrossRef]

4. Mishra, M.; Chandak, S.; Rout, P.K. Taxonomy of Islanding detection techniques for distributed generation in microgrid. Renew. Energy Focus 2019, 31, 9-30. [CrossRef] 
5. Dutta, S.; Sadhu, P.K.; Reddy, M.J.B.; Mohanta, D.K. Shifting of research trends in islanding detection method-A comprehensive survey. Prot. Control Mod. Power Syst. 2018, 3, 1-20. [CrossRef]

6. Abd-Elkader, A.G.; Saleh, S.M.; Eiteba, M.M. A passive islanding detection strategy for multi-distributed generations. Int. J. Electr. Power Energy Syst. 2018, 99, 146-155. [CrossRef]

7. IEEE Standard Association. 1547-2018-IEEE Standard for Interconnection and Interoperability of Distributed Energy Resources with Associated Electric Power Systems Interfaces; IEEE: Piscataway, NJ, USA, 2018.

8. Papadimitriou, C.; Kleftakis, V.; Hatziargyriou, N. A novel islanding detection method for microgrids based on variable impedance insertion. Electr. Power Syst. Res. 2015, 121, 58-66. [CrossRef]

9. Karimi, M.; Mokhlis, H.; Naidu, K.; Uddin, S.; Bakar, A. Photovoltaic penetration issues and impacts in distribution network-A review. Renew. Sustain. Energy Rev. 2016, 53, 594-605. [CrossRef]

10. Bayrak, G.; Kabalci, E. Implementation of a new remote islanding detection method for wind-solar hybrid power plants. Renew. Sustain. Energy Rev. 2016, 58, 1-15. [CrossRef]

11. Zeineldin, H.H.; Salama, M.M.A. Impact of Load Frequency Dependence on the NDZ and Performance of the SFS Islanding Detection Method. IEEE Trans. Ind. Electron. 2009, 58, 139-146. [CrossRef]

12. Jou, H.-L.; Chiang, W.-J.; Wu, J.-C. Virtual inductor-based islanding detection method for grid-connected power inverter of distributed power generation system. IET Renew. Power Gener. 2007, 1, 175-181. [CrossRef]

13. Chiang, W.-J.; Jou, H.-L.; Wu, J.-C. Active islanding detection method for inverter-based distribution generation power system. Int. J. Electr. Power Energy Syst. 2012, 42, 158-166. [CrossRef]

14. Murugesan, S.; Murali, V.; Daniel, S.A. Hybrid Analyzing Technique for Active Islanding Detection Based on d-Axis Current Injection. IEEE Syst. J. 2017, 12, 3608-3617. [CrossRef]

15. Shrivastava, S.; Jain, S.; Nema, R.K.; Chaurasia, V. Two level islanding detection method for distributed generators in distribution networks. Int. J. Electr. Power Energy Syst. 2017, 87, 222-231. [CrossRef]

16. Velasco, D.; Trujillo, C.; Garcera, G.; Figueres, E. An active anti-islanding method based on phase-PLL perturbation. IEEE Trans. Power Electron. 2010, 26, 1056-1066. [CrossRef]

17. Reigosa, D.; Briz, F.; Charro, C.B.; García, P.; Guerrero, J.M. Active islanding detection using high-frequency signal injection. IEEE Trans. Ind. Appl. 2012, 48, 1588-1597. [CrossRef]

18. Bayrak, G. A remote islanding detection and control strategy for photovoltaic-based distributed generation systems. Energy Convers. Manag. 2015, 96, 228-241. [CrossRef]

19. Pinto, S.J.; Panda, G. Wavelet technique based islanding detection and improved repetitive current control for reliable operation of grid-connected PV systems. Int. J. Electr. Power Energy Syst. 2015, 67, 39-51. [CrossRef]

20. Mohamad, H.; Mokhlis, H.; Abu Bakar, A.H.; Ping, H.W. A review on islanding operation and control for distribution network connected with small hydro power plant. Renew. Sustain. Energy Rev. 2011, 15, 3952-3962. [CrossRef]

21. Heidari, M.; Seifossadat, G.; Razaz, M. Application of decision tree and discrete wavelet transform for an optimized intelligentbased islanding detection method in distributed systems with distributed generations. Renew. Sustain. Energy Rev. 2013, 27, 525-532. [CrossRef]

22. Bakhshi, R.; Sadeh, J. Voltage positive feedback based active method for islanding detection of photovoltaic system with string inverter using sliding mode controller. Sol. Energy 2016, 137, 564-577. [CrossRef]

23. Gupta, P.; Bhatia, R.S.; Jain, D.K. Average Absolute Frequency Deviation Value Based Active Islanding Detection Technique. IEEE Trans. Smart Grid 2015, 6, 26-35. [CrossRef]

24. Al Hosani, M.; Qu, Z.; Zeineldin, H.H. A Transient Stiffness Measure for Islanding Detection of Multi-DG Systems. IEEE Trans. Power Deliv. 2014, 30, 986-995. [CrossRef]

25. Pai, F.-S.; Huang, S.-J. A detection algorithm for islanding-prevention of dispersed consumer-owned storage and generating units. IEEE Trans. Energy Convers. 2001, 16, 346-351. [CrossRef]

26. Khamis, A.; Shareef, H.; Mohamed, A.; Bizkevelci, E. Islanding detection in a distributed generation integrated power system using phase space technique and probabilistic neural network. Neurocomputing 2015, 148, 587-599. [CrossRef]

27. Aljankawey, A.S.; Liu, N.; Diduch, C.P.; Chang, L. A new passive islanding detection scheme for distributed gen-eration systems based on wavelets. In Proceedings of the 2012 IEEE Energy Conversion Congress and Exposition (ECCE), Raleigh, NC, USA, 15-20 September 2012; pp. 4378-4382.

28. Faqhruldin, O.N.; El-Saadany, E.F.; Zeineldin, H.H. A universal islanding detection technique for distributed generation using pattern recognition. IEEE Trans. Smart Grid 2014, 5, 1985-1992. [CrossRef]

29. Raza, S.; Mokhlis, H.; Arof, H.; Laghari, J.A.; Mohamad, H. A Sensitivity Analysis of Different Power System Parameters on Islanding Detection. IEEE Trans. Sustain. Energy 2016, 7, 461-470. [CrossRef]

30. Raza, S.; Rahman, T.U.; Saeed, M.; Jameel, S. Performance analysis of power system parameters for islanding detection using mathematical morphology. Ain Shams Eng. J. 2020, 12, 517-527. [CrossRef]

31. Kolli, A.T.; Ghaffarzadeh, N. A novel phaselet-based approach for islanding detection in inverter-based distributed generation systems. Electr. Power Syst. Res. 2020, 182, 106226. [CrossRef]

32. Mishra, P.P.; Bhende, C.N.; Manikandan, M.S. Islanding detection using total variation-based signal decomposition technique. IET Energy Syst. Integr. 2020, 2, 22-31. [CrossRef] 
33. Nale, R.; Biswal, M.; Kishor, N. A Transient Component Based Approach for islanding detection in distributed generation. IEEE Trans. Sustain. Energy 2018, 10, 1129-1138. [CrossRef]

34. Basso, T. IEEE 1547 and 2030 Standards for Distributed Energy Resources Interconnection and Interoperability with the Electricity Grid. Nrel 2014. [CrossRef]

35. Reddy, C.R.; Reddy, K.H. A New Passive Islanding Detection Technique for Integrated Distributed Generation System Using Rate of Change of Regulator Voltage Over Reactive Power at Balanced Islanding. J. Electr. Eng. Technol. 2019, 14, 527-534. [CrossRef]

36. Nikolovski, S.; Baghaee, H.R.; Mlakic, D. Islanding Detection of Synchronous Generator-Based DGs using Rate of Change of Reactive Power. IEEE Syst. J. 2019, 13, 4344-4354. [CrossRef]

37. Xie, X.; Huang, C.; Li, D. A new passive islanding detection approach considering the dynamic behavior of load in microgrid. Int. J. Electr. Power Energy Syst. 2020, 117, 105619. [CrossRef]

38. Admasie, S.; Bukhari, S.B.A.; Haider, R.; Gush, T.; Kim, C.H. A passive islanding detection scheme using variation-al mode decomposition-based mode singular entropy for integrated microgrids. Electr. Power Syst. Res. 2019, 177, 105983. [CrossRef]

39. Dhua, R.; Chatterjee, D.; Goswami, S.K. Harmonic filter-based improved islanding detection technique for microgrid. IET Renew. Power Gener. 2019, 13, 2443-2450. [CrossRef]

40. Pourbabak, H.; Kazemi, A. Islanding detection method based on a new approach to voltage phase angle of constant power inverters. IET Gener. Transm. Distrib. 2016, 10, 1190-1198. [CrossRef]

41. Pourbabak, H.; Kazemi, A. A new technique for islanding detection using voltage phase angle of inverter-based DGs. Int. J. Electr. Power Energy Syst. 2014, 57, 198-205. [CrossRef]

42. Abyaz, A.; Panahi, H.; Zamani, R.; Alhelou, H.H.; Siano, P.; Shafie-Khah, M.; Parente, M. An Effective Passive Islanding Detection Algorithm for Distributed Generations. Energies 2019, 12, 3160. [CrossRef]

43. Subramanian, K.; Loganathan, A.K. Islanding Detection Using a Micro-Synchrophasor for Distribution Systems with Distributed Generation. Energies 2020, 13, 5180. [CrossRef]

44. Serrano-Fontova, A.; Martinez, J.A.; Casals-Torrens, P.; Bosch, R. A robust islanding detection method with zero-non-detection zone for distribution systems with DG. Int. J. Electr. Power Energy Syst. 2021, 133, 107247. [CrossRef]

45. Bakhshi-Jafarabadi, R.; Sadeh, J.; Popov, M. Maximum power point tracking injection method for islanding detection of gridconnected photovoltaic systems in microgrid. IEEE Trans. Power Deliv. 2020, 36, 168-179. [CrossRef]

46. Michas, M.; Ugalde-Loo, C.E.; Jenkins, N. Grid code compliance and ancillary services provision from DFIG and FRC-based wind turbines. In Proceedings of the 2016 51st International Universities Power Engineering Conference (UPEC), Coimbra, Portugal, 6-9 September 2016; IEEE: Piscataway, NJ, USA; pp. 1-6.

47. Zeineldin, H.; El-Saadany, E.; Salama, M. Impact of DG Interface Control on Islanding Detection and Nondetection Zones. IEEE Trans. Power Deliv. 2006, 21, 1515-1523. [CrossRef] 